Отримано: 02 жовтня 2019 р.

Прорецензовано: 11 жовтня 2019 р.

Прийнято до друку: 22 жовтня 2019 р.

e-mail: pawel.dziekanski@ujk.edu.pl

adrianlipa@konsorcjum.edu.pl

DOI: 10.25264/2311-5149-2019-15(43)-60-67
Paweł Dziekański, Adrian Lipa, Urszula Karpińska. Assessment and spatial diversity of the competitiveness of communes of the Świetokrzyskie province. Наукові записки Національного університету «Острозька академія». Серія «Економіка» : науковий журнал. Острог : Вид-во НаУОА, грудень 2019. № 15(43). С. 60-67.

УДК: 332.146 .2

JEL-класфікаиія: L26, R11, R12, R51, R58, Q56

Pawel Dziekański,

PhD, Institute of Law, Economics and Administration, Jan Kochanowski University in Kielce, Poland

Adrian Lipa,

Scientific and Educational Consortium, Poland

Urszula Karpińska,

Cooperative Bank in Kielce, Poland

\title{
ASSESSMENT AND SPATIAL DIVERSITY OF THE COMPETITIVENESS OF COMMUNES OF THE ŚWIĘTOKRZYSKIE PROVINCE
}

The commune is the basic local government unit. It has a certain range of freedom in deciding on the path of development and property. The commune's process of activity takes place in a space that is entirely filled by the natural and economic environment, and its specific, individual features of the economy, society and resources. The aim of the article is to analyze the spatial disproportions in the competitiveness of poviats of the Swiętokrzyskie Voivodship using a synthetic measure. As the source material, data from the Regional Accounting Chamber (Kielce branch) and Local Database of the Central Statistical Office for 2009, 2011 and 2017 were used. The competitiveness of the local economy is largely dependent on the processes taking place in the so-called development centers and the availability of endogenous resources. The center can get rich at the expense of peripheral areas (e.g. by attracting human capital). Włoszczowski, Kielecki and Buski poviats were high in the ranking. At the other end of the ranking were Pińczowski, Skarżyski, Kazimierski. The synthetic measure in 2017 ranged from 0.52 (Włoszczowski) to 0.73 (Kazimierksi), in 20090.53 (Staszowski) to 0.79 (Kazimierski) respectively. No position stability was observed in the ranking, the level of the indicator is influenced by: the economic nature of the unit and the function of the area (industrial, tourist, residential), economic potential, financial situation, natural environment and infrastructure. Therefore, the assessment should take into account local specificities in various structural and functional conditions.

Key words: competitiveness, synthetic measure, commune, Świętokrzyskie Province.

Джсканьський Павел,

Доктор філософії, Факультет права, управління і менеджменту, Університет ім. Я. Кохановського у Кєльие, Польща

Ліпа Адріан,

Науковий та освітній консориіум, Польщза

Карпіньська Уршула,

Кооперативний банк у Кельщее, Польщза

\section{ОЦІНКА ТА ПРОСТОРОВЕ РІЗНОМАНІТТЯ КОНКУРЕНТОСПРОМОЖНОСТІ КОМУН У СВЕНТОКШИСЬКОМУ ВОСВОДСТВІ}

Комуна є основною одиницею місиевого самоврядування. Вона має певний діапазон свободи у вирішенні шляху розвитку та власності. Процес діяльності громади відбувається в просторі, повністю заповненому природним та економічним середовищем та його специфічними, індивідуальними особливостями економіки, суспільства та ресурсів. Метою статті є аналіз просторових диспропориій у конкурентоспроможності повітів Свентокииського воєводства за допомогою синтетичного заходу. У якості вихідного матеріалу були використані дані Регіональної бухгалтерської палати (філія Кільце) та Місиевої бази даних Центрального статистичного управління за 2009 , 2011 та 2017 роки. Конкурентоспроможність місцевої економіки значною мірою залежить від прочесів, щзо відбуваються у так званих иентрах розвитку, та наявності ендогенних ресурсів. Центр може розбагатіти за рахунок периферійних районів (наприклад, за рахунок залучення людського капіталу). Височевські, Кілечькі та Буські пов'язки були високими в рейтингу. На іншому кінці рейтингу опинилися Піньчовський, Скаржсиський, Казімірський. Синтетичний захід 2017 року становив від 0,52 (Włoszczowski) до 0,73 (Kazimierksi), 2009 року - вid 0,53 (Staszowski) до 0,79 (Kazimierki) відповідно. Стабільності позицій у рейтингу не спостерігалось, на рівень показника впливають економічний характер одиниці та функиія району (промисловий, туристичний, житловий), економічний потенціал, фінансове становище, природне середовище та інфраструктура. Тому оцінка повинна враховувати місиеві особливості в різних структурних та функиійних умовах.

Ключові слова: Конкурентоспроможність, синтетичний захід, комуна, Свєнтокшиське воєводство. 


\title{
Джеканьский Павел, \\ Доктор философии, Факультет права, управления и менеджмента, Университет им. Я. Кохановського в Кельце, Польша
}

Липа Адриан,

Науковий и образовательный консориуум, Польша

Карпиньска Уршула,

Кооперативный банк в Кельщее, Польщ̧а

\section{ОЦЕНКА И ПРОСТРАНСТВЕННОЕ МНОГООБРАЗИЕ КОНКУРЕНТОСПОСОБНОСТИ КОММУН В СВЕНТОКШИСКОМ ВОЄВОДСТВЕ}

\begin{abstract}
Коммуна является основной единицей местного самоуправления. Она обладает определенной степенью свободы при выборе пути развития и собственности. Процесс деятельности коммуны происходит в пространстве, которое полностью заполнено природной и экономической средой и ее специфическими индивидуальными особенностями экономики, общества и ресурсов. Целью статьи является анализ пространственных диспропориий в конкурентоспособности повятов Свентокииского воеводства с использованием синтетической меры. В качестве исходного материала использовались данные из Региональной Счетной палаты (Кельикий филиал) и Локальной базы данныхх Центрального статистического управления за 2009, 2011 и 2017 г2. Конкурентоспособность местной экономики в значительной степени зависит от прочессов, происходящих в так называемых центры развития и наличие эндогенных ресурсов. Центр может разбогатеть за счет периферийных районов (например, путем привлечения человеческого капитала). Włoszczowski, Кельце и Буски повяты были высокими в рейтинге. На другом конце рейтинга были Пиньчув, Скаржсиски, Казимеж. Синтетический показатель в 2017 году варьировался от 0,52 (Влоилавек) до 0,73 (Казимеж), в 2009 году - 0,53 (Сташовский) до 0,79 (Казимеж) соответственно. Стабильности позиичии в рейтинге не наблюдалось, на уровень индикатора влияют: экономический характер объекта и функиии района (промышленный, туристический, жилой), экономический потенциал, финансовое положение, природная среда и инфраструктура. Поэтому при оценке следует учитывать местные особенности в различных структурных и функциональных условиях.
\end{abstract}

Ключевые слова: Конкурентоспособность, синтетическая мера, коммуна, Свентокшишское воеводство

\section{Introduction}

The commune is the basic local government unit. Has a certain range of freedom in deciding on the path of development, property. It implements the scope of public tasks, in particular in the aspect of technical infrastructure, social infrastructure, protection and public security as well as spatial and ecological order ${ }^{1}$. The environment and the economy form a network of interconnections in which tasks are carried out. Endogenous resources, acting for the benefit of the community, are interdependent and should be considered together ${ }^{2}$. Today, communes have become the subjects of economic processes. They pursue the interests of given communities, taking into account local resources. Their actions depend on both endogenous and exogenous factors. The commune's process of activity takes place in a space that is fully filled by the natural and economic environment, and its specific, individual features of the economy, society and resources ${ }^{3}$.

Building the region's competitiveness requires stimulating its various determinants (environmental, social and economic). The activity of these units is focused on the use of available endogenous resources ${ }^{4}$, e.g. raw materials, economic, social and natural capital, finances and human resources ${ }^{5}$. The competitive advantage of municipalities is not determined by the region's ability to configure various tangible and intangible resources, as a result of which new values are created ${ }^{6}$. Competitiveness (development) of communes is a complex phenomenon, difficult to clearly and objectively assess from the point of view of the examined aspect of the structure, which cannot be measured and expressed by means of one feature ${ }^{7}$. The problem with assessing the operation of municipalities

\footnotetext{
${ }^{1}$ Ustawa z dnia 8 marca 1990 r. o samorządzie gminnym (Dz. U. z 2001 r. Nr 142, poz. 1591 z późn. zm.); K. Podgórski, 1991, Ustawowa regulacja zadań gminy jako jednostki samorządu terytorialnego, ST, nr 11-12, p. 21.

2 J. Zaucha, 2012, Synteza aktualnego stanu wiedzy dotyczącej rozwoju sustensywnego i spójności terytorialnej w planowaniu przestrzennym (analiza dokumentów UE, BSR i PL), [In:] Planowanie przestrzenne w rozwoju zrównoważonym, Inspiracje Projektu EcoRegion, część I, UG, Gdańsk; A. Zakrzewska-Półtorak, 2011, Zasoby endogeniczne jako czynnik rozwoju lokalnego i regionalnego. Studium przypadków wybranych gmin województwa dolnośląskiego, Prace Naukowe Uniwersytetu Ekonomicznego we Wrocławiu, nr 152, p. 579-588.

${ }_{3}^{3}$ D. Rynio, 2013, Kształtowanie nowej polityki regionalnej Polski w warunkach globalizacji i integracji, Monografie i Opracowania Uniwersytetu Ekonomicznego we Wrocławiu, nr 240, p. 357.

${ }^{4}$ J.J. Parysek, 2001, Podstawy gospodarki lokalnej, Wyd. Nauk. Uniwersytetu Adama Mickiewicza, Poznań.

5 W. Kisiała, B. Stępiński (ed.), 2013, Rola obszarów metropolitalnych w polityce regionalnej i rozwoju regionalnym, Wydawnictwo UE w Poznaniu, Poznań.

${ }^{6}$ T. Markowski, D. Stawasz (ed.), 2001, Ekonomiczne i środowiskowe aspekty zarządzania rozwojem miast i regionów, Łódź, p. 91.

F. Wysocki, 2010, Metody taksonomiczne w rozpoznawaniu typów ekonomicznych rolnictwa i obszarów wiejskich, Wydawnictwo Uniwersytetu Przyrodniczego w Poznaniu, Poznań.
} 
is the relatively large amount of information that creates information noise. It impedes the analyzes carried out, increases the research effort, and also makes it more difficult to make clear decisions. Support in the decisionmaking process can be the creation of synthetic measures with high information capacity or leaving those measures that have the greatest information value ${ }^{8}$.

\section{Aim and research method}

The aim of the article is to analyze the spatial disproportions in the competitiveness of poviats of the Świętokrzyskie Voivodship using a synthetic measure (a synthetic measure based on distance in real space with Euclidean metrics). As the source material, data from the Regional Accounting Chamber (Kielce branch) and Local Database of the Central Statistical Office for 2009, 2011 and 2017 were used.

In order to determine the measure of synthetic competitiveness, the following procedure was used:

1. The variables describing competitiveness were selected. The ones with low spatial variability and high correlation of variables were removed from the set of variables (according to the inverted matrix method) ${ }^{10}$.

2. The variables were subjected to the zero unitarisation procedure using the following formulas:

$$
\begin{aligned}
& \text { for stimulants } z_{i j}=\frac{\mathrm{x}_{i j}-\min _{i} \mathrm{x}_{i j}}{\max _{i} \mathrm{x}_{i j}-\min _{i} x_{i j}}, \operatorname{gdy} x_{i} \in S \\
& \text { for destimulants } z_{i j}=\frac{\max _{i} \mathrm{x}_{i j}-\mathrm{x}_{i j}}{\max _{i} \mathrm{x}_{i j}-\min _{i} \mathrm{x}_{i j}}, \operatorname{gdy} x_{i} \in D
\end{aligned}
$$

where: S-stimulant, D-destimulant; $i=1,2 \ldots n ; j=1,2 \ldots n, x i j-$ means the value of the $j$-t feature for the tested unit, $\max$ - the maximum value of the $\mathrm{j}-\mathrm{t}$ feature, min - the minimum value of the $\mathrm{j}$ - $\mathrm{t}$ feature ${ }^{11}$.

3. A synthetic measure based on distance in real space was calculated with Euclidean metric according to the formula:

$$
O E_{i t}=\sqrt{\frac{1}{p} \sum_{j=1}^{p}\left(1-z_{i j t}\right)^{2}}
$$

where: $\mathrm{i}=1,2 \ldots \mathrm{N} ; \mathrm{j}=1,2 \ldots, \mathrm{p}$ ( $\mathrm{N}$ is the number of objects (poviats), and $\mathrm{p}$ - number of features), $\mathrm{zij}-\mathrm{is}$ the value of the $\mathrm{j}$-th feature for the unit being tested ${ }^{12}$. The synthetic measure allows measuring measured to the interval $[0 ; 1]$. A measure value of 0 means the maximum positive value of each stimulant tested ${ }^{13}$.

4. The studied area of rural communes in the Świętokrzyskie voivodship was divided into 4 quartile groups. The size of the indicator in the first group means a better unit, in the last one the weakest ${ }^{14}$.

\section{The essence of the region's competitiveness}

K. Kuciński defines the competitiveness of the region as a resultant of possessed resources and their distribution, development to date, conscious activities of public authorities aiming at shaping the face of the region ${ }^{15}$. T. Markowski defines the competitiveness of regions in the objective sense, indicating that it is the ability of regions to meet the needs and demand for services and goods from local and global markets. This should provide regions with a sustainable income opportunity ${ }^{16}$. In turn, A. Klasik treats the region's competitiveness as a result of the attractiveness of the service offer, the region's strengths, export strength, and productivity ${ }^{17}$.

The competitiveness of regions is their ability to produce sustainable growth in value added. It is based on the efficient and effective use of resources and management of economic processes in the regional economy. The

${ }^{8}$ A. Adamczyk, D. Dawidowicz, 2016, Wartość informacyjna wskaźników oceny kondycji finansowej jednostek samorządu terytorialnego, Ekonomiczne Problemy Usług nr 125, p. 25-36.

${ }^{9}$ P. Dziekański, Spatial changes and assessment of the financial condition of local government units in the context of the income structure [In:] Formankova S., International Conference on Management (ICoM), Trends of Management in the Contemporary Society (Peer-Reviewed Conference Proceedings), Brno 2016, Publisher: Mendelova univerzita v Brně.

${ }^{10}$ A. Malina, 2004, Wielowymiarowa analiza przestrzennego zróżnicowania struktury gospodarki Polski według województw, Wyd. Akademii Ekonomicznej w Krakowie, Kraków, p. 96-97.

${ }^{11}$ P. Dziekański, 2016, Spatial Differentiation of the Financial Condition of the Świętokrzyskie Voivodship Counties, Barometr Regionalny, Tom $14 \mathrm{nr}$ 3; E. Mioduchowska-Jaroszewicz, 2013, Metody i kierunki oceny kondycji finansowej jednostek samorządów terytorialnych, ZN US, nr 786, Finansowe, Ubezpieczenia, nr 64/2. p. 127-140; K. Kukuła, 2000, Metoda unitaryzacji zerowanej, PWN, Warszawa; A. Młodak, 2006, Analiza taksonomiczna w statystyce regionalnej, Difin, Warszawa.

${ }^{12}$ F. Wysocki, 1996, Metody statystycznej analizy wielowymiarowej w rozpoznawaniu typów struktury przestrzennej rolnictwa, Roczniki AR w Poznaniu, seria: Rozprawy Naukowe, z. 266, Poznań.

${ }^{13}$ M. Trojak, T. Tokarski (ed.), 2013, Statystyczna analiza przestrzennego zróżnicowania rozwoju ekonomicznego i społecznego Polski, Wyd. UJ, Kraków.

${ }^{14}$ P. Dziekański, A. Wyszkowski, 2018, Ocena przestrzennego zróżnicowania sytuacji finansowej gmin województwa świętokrzyskiego z wykorzystaniem miary syntetycznej, Optimum. Economic Studies, nr 1 (91), p. 219-238; F. Wysocki, J. Lira, 2005, Statystyka opisowa, Wydawnictwo Uniwersytetu Przyrodniczego w Poznaniu, Poznań.

${ }^{15}$ K. Kuciński, 1997, Konkurencyjność jako zagadnienie regionalne, IFGN, SGH, Warszawa, s. 1.

${ }^{16}$ T. Markowski, Przedmiotowa i podmiotowa konkurencyjność regionów [In:] T. Czyż, H. Rogacki (red.), Współczesne problemy i koncepcje teoretyczne badań przestrzenno-ekonomicznych, z. 219, PAN KPZK, Warszawa 2005, p. $28-30$.

${ }^{17}$ A. Klasik, 2002, Strategie regionalne. Formułowanie i wprowadzanie w życie, AE, Katowice, p. 22-23. 
element shaping competitiveness is the use of an appropriate combination of internal and external growth factors, directed among others to shape the region's attractiveness for foreign investors and to stimulate the creativity and aggressiveness of local investors ${ }^{18}$.

The competitiveness of regions is determined by factors that can be classified as spatial, social and organizational. All competitiveness factors of the region fall into the category of development factors of the region ${ }^{19}$. It is shaped to the greatest extent by endogenous factors, otherwise known as local opportunities and development needs (demographic resources, infrastructure and economy). The features related to access and quality of individual factors from this group are important. Exogenous (external) factors refer to changes in macro-environment, which result, among others, from changing macroeconomic conditions, system changes in the state. An important factor is also the financial resources that are essential for the optimal functioning of local governments ${ }^{20}$.

The basis of the regions' competitiveness is the high efficiency of the local economy. It ensures that the public enjoys a high and growing standard of living and a high employment rate. Regions often do not form a compact whole, and their elements develop at different rates and with different intensities. The consequence of this is the process of flow of resources from local to central centers. On the one hand, the captain is looking for areas with a higher rate of return, lower investment risk, an efficient institutional environment and highly qualified employees. On the other hand, a qualified workforce migrates in search of employment, ensuring better conditions for development ${ }^{21}$.

The multidimensionality of the functioning of local government units is demonstrated by the directions of action and the benefits achieved in the spatial, social, economic aspects, etc. The scope and effectiveness of the influence of local authorities on local and regional development are determined by income and expenditure instruments. They can be used by local authorities depending on the division of competences and powers between government and local institutions ${ }^{22}$. These activities are usually focused around goals, among which should be distinguished long-term development, increase in income of residents and the budget, development of entrepreneurship ${ }^{23}$.

\section{Intra-regional diversification of the competitiveness of poviats of the Świętokrzyskie voivodship}

The Świętokrzyskie Voivodship belongs to the ecologically cleanest areas of Poland. The region has an industrial and agricultural character with a high concentration of industry sectors related to the production and processing of metals, mining and processing of mineral resources and the production of foodstuffs.

The main industries of the Świętokrzyskie region are: metallurgical (Ostrowiec Świętokrzyski), metal (Skarżysko-Kamienna), machine (Starachowice), building materials (Kielce), ceramic, foundry (Końskie), food (Pińczów, Kielce). The economy of the Świętokrzyskie region is based on the mining industry in the field of building materials (limestone, dolomite, marl, gypsum, sandstone), thanks to which the voivodship became the capital of Polish construction. The agricultural south is the base for the production of organic food (table 1$)^{24}$.

Characteristics of selected areas (poviats) of the Świętokrzyskie Voivodeship

Table 1.

\begin{tabular}{|l|l|}
\hline \multicolumn{1}{|c|}{ Poviats } & \multicolumn{1}{c|}{ Characteristic } \\
\hline Kielce & Food and construction industry \\
\hline Kielecki & Mining and processing industry for mineral raw materials, food production \\
\hline Konecki & Foundry, construction, trade, hotel industry, transport \\
\hline Ostrowiecki & Iron metallurgy, trade, services \\
\hline Skarżyski & Metal industry, agriculture, trade and services, construction \\
\hline Starachowicki & Machine and metal industry \\
\hline Buski & Agriculture (vegetables, orchards), agrotourism, spas \\
\hline
\end{tabular}

${ }_{18}$ J. Chądzyński, A. Nowakowska, Z. Przygodzki, 2007, Region i jego rozwój w warunkach globalizacji, Wyd. CeDeWu, Warszawa, p. 106.

${ }_{19}$ W. Kosiedowski, 2008, Zarządzanie rozwojem regionalnym i lokalnym [In:] Gospodarka regionalna i lokalna, red. Z. Strzelecki, PWN, Warszawa, p. 232 i n.

${ }^{20}$ Z. Oplotnik, B. Brezovnik, 2004, Financing local government in Slovenia, Post-Communist Economies, Volume 16, Issue 4.

${ }^{21}$ T. Kudłacz, 2001, Rozwój regionalny Polski lat 90. - ocena dominujących procesów oraz spodziewanych tendencji [In:] Polityka regionalna państwa pośród uwikłań instytucjonalno-regulacyjnych, red. Szomburg J., IBnGR, Gdańsk, p. 30; T. Markowski, 2001, Stymulowanie i regulowanie konkurencyjności w świetle procesów globalizacji gospodarki, Samorząd Terytorialny, nr 3, p. 30.

${ }^{22}$ L. Patrzałek, 2010, Finanse samorządu terytorialnego a koncepcje rozwoju lokalnego i regionalnego, Prace Naukowe Uniwersytetu Ekonomicznego we Wrocławiu 112, Finanse publiczne, p. 549-556

${ }^{23}$ P. Dziekański, 2018, Ocena efektywności funkcjonowania gmin województwa świętokrzyskiego w świetle ekonomii instytucjonalnej (analiza wielowymiarowa), Uniwersytet Jana Kochanowskiego w Kielcach, Kielce

${ }_{24}$ M.A. Jóźwiak, M. Jóźwiak, M. Strzyż, 2010, Predyspozycje naturalne regionu świętokrzyskiego do rozwoju turystyki, Krajobraz a Turystyka, Prace Komisji Krajobrazu Kulturowego Nr 14, Komisja Krajobrazu Kulturowego PTG, Sosnowiec. 


\begin{tabular}{|l|l|}
\hline Jędrzejowski & Agriculture, agrotourism, agri-food processing \\
\hline Kazimierski & Agriculture, construction, trade, services \\
\hline Opatowski & Agriculture, agrotourism, industry (cement), dairy \\
\hline Pińczowski & Agriculture, trade, services, mining industry \\
\hline Sandomierski & Agriculture (gardening, orchards), agrotourism, industry (glassworks) \\
\hline Staszowski & Agriculture, trade, services \\
\hline Włoszczowski & Agriculture, trade, services, recreation \\
\hline
\end{tabular}

Źródło: Bury P., Dziekański P., 2013, Ocena kondycji finansowej powiatów województwa świętokrzyskiego w latach 20072011 za pomocą wskaźnika syntetycznego, s. 220-248 [w:] Czynniki zmian zjawisk regionalnych, V. Jurcak, P. Dziekański (red.), Czynniki zmian zjawisk regionalnych, Wyd. WSBiP Ostrowiec Św., Ostrowiec Św.

The value of the synthetic measure allowed dividing the communes of the Świętokrzyskie Province into 4 groups. Small groups in time and space can be observed between the groups. Włoszczowski, Kielcki and Buski poviats were high in the ranking. At the other end of the ranking were Pińczowski, Skarżyski, Kazimierski. The synthetic measure in 2017 ranged from 0.52 (Włoszczowski poviat, best unit) to 0.73 (Kazimierski, the weakest unit), in 20090.53 (Staszowski) to 0.79 (Kazimierski) respectively.

Table 2.

Quartile groups measures of synthetic competitiveness (OE)

of poviats of the Świętokrzyskie voivodship in 2009, 2011, 2017

\begin{tabular}{|c|c|c|c|c|c|c|}
\hline & \multicolumn{2}{|c|}{2009} & \multicolumn{2}{|c|}{2011} & \multicolumn{2}{|c|}{2017} \\
\hline $\mathrm{A}$ & staszowski & 0.53 & staszowski & 0.5 & \begin{tabular}{|lr}
\multicolumn{2}{|l}{ włoszczowski } \\
kielecki & 0.54 \\
buski & 0.55 \\
jędrzejowski
\end{tabular} & 0.52 \\
\hline B & $\begin{array}{l}\text { kielecki } 0.59 \\
\text { jędrzejowski } \\
\text { opatowski } \\
\text { buski } \quad 0.63 \\
\end{array}$ & $\begin{array}{l}0.62 \\
0.62\end{array}$ & \begin{tabular}{|lc}
\multicolumn{2}{|l}{ włoszczowski } \\
kielecki & 0.59 \\
jędrzejowski \\
buski $\quad 0.62$ \\
\end{tabular} & $\begin{array}{l}0.58 \\
0.6\end{array}$ & \begin{tabular}{|l}
\multicolumn{2}{|l}{ staszowski } \\
konecki 0.57 \\
sandomierski
\end{tabular} & $\begin{array}{l}0.56 \\
0.63\end{array}$ \\
\hline $\mathrm{C}$ & $\begin{array}{l}\text { włoszczowski } \\
\text { konecki } 0.65 \\
\text { ostrowiecki } \\
\text { sandomierski }\end{array}$ & $\begin{array}{l}0.64 \\
0.66 \\
0.66\end{array}$ & \begin{tabular}{l}
\multicolumn{2}{|l}{ sandomierski } \\
konecki 0.66
\end{tabular} & 0.64 & \begin{tabular}{|l} 
opatowski \\
starachowicki \\
ostrowiecki
\end{tabular} & $\begin{array}{l}0.64 \\
0.64 \\
0.66\end{array}$ \\
\hline $\mathrm{D}$ & $\begin{array}{l}\text { pińczowski } \\
\text { starachowicki } \\
\text { skarżyski } 0.75 \\
\text { kazimierski }\end{array}$ & $\begin{array}{l}0.72 \\
0.74 \\
0.79\end{array}$ & $\begin{array}{l}\text { ostrowiecki } \\
\text { pińczowski } \\
\text { opatowski } \\
\text { starachowicki } \\
\text { skarżyski } 0.74 \\
\text { kazimierski }\end{array}$ & $\begin{array}{l}0.68 \\
0.68 \\
0.7 \\
0.71 \\
\\
\\
0.78\end{array}$ & $\begin{array}{l}\text { pińczowski } \\
\text { skarżyski } 0.71 \\
\text { kazimierski }\end{array}$ & $\begin{array}{l}0.68 \\
0.73\end{array}$ \\
\hline
\end{tabular}
Office

Source: own calculations of the authors based on the data from the Local Data Bank of Statistics Poland and Central Statistical

In the ranking, no position stability was observed, the level of the indicator is affected by: the economic nature of the unit and the function of the area (industrial, tourist, residential), economic potential, financial situation, natural environment and infrastructure (location rent). Therefore, the assessment should take into account local specificities in various structural and functional conditions.

Measures of spatial diversity indicate the relative stability of poviats in terms of competitiveness. In 2017 , compared to 2009, the results show stability according to the standard deviation (0.07-0.07). The classic coefficient of variation (0.11-0.11) also indicates the stability of diversity. The values of the range 0.26 (2009) and 0.21 (2017) indicate slight changes in the area under study, a decrease in the diversity of poviats.

Table 3.

Measures of diversification of the measure of synthetic competitiveness (OE) of poviats of the Świętokrzyskie Voivodship in 2009, 2011, 2017

\begin{tabular}{|l|c|c|c|}
\hline & $\mathbf{2 0 0 9}$ & $\mathbf{2 0 1 1}$ & $\mathbf{2 0 1 7}$ \\
\hline average & 0,66 & 0,65 & 0,61 \\
\hline median & 0,65 & 0,66 & 0,63 \\
\hline standard deviation & 0,07 & 0,07 & 0,07 \\
\hline quarter (quartile) deviation & 0,67 & 0,65 & 0,61 \\
\hline
\end{tabular}




\begin{tabular}{|c|c|c|c|}
\hline classic coefficient of variation & 0,11 & 0,11 & 0,11 \\
\hline positional coefficient of variation & 1,03 & 0,98 & 0,96 \\
\hline $\min$ & 0,53 & 0,50 & 0,52 \\
\hline $\max$ & 0,79 & 0,78 & 0,73 \\
\hline gap & 0,26 & 0,28 & 0,21 \\
\hline quartile range & 0,10 & 0,10 & 0,11 \\
\hline slant & 0,18 & $-0,29$ & 0,26 \\
\hline measure of concentration-kurtosis & $-0,15$ & 0,14 & $-1,31$ \\
\hline
\end{tabular}

Source: own calculations of the authors based on the data from the Local Data Bank of Statistics Poland and Central Statistical Office

The Pearson correlation coefficient between the value of the synthetic measure of development in 2009 and 2011 was -0.893 , in the case of the 2011-2017 relation -0.856 (Figure 1). We observe convergence in the area of poviat competitiveness. It can be assumed that the spatial diversity of the studied area was quite stable, and the units reacted similarly to changes in the economy.

Figure 1. Scatter chart of the ratio of synthetic competitiveness measures year to year by poviats Świętokrzyskie voivodship

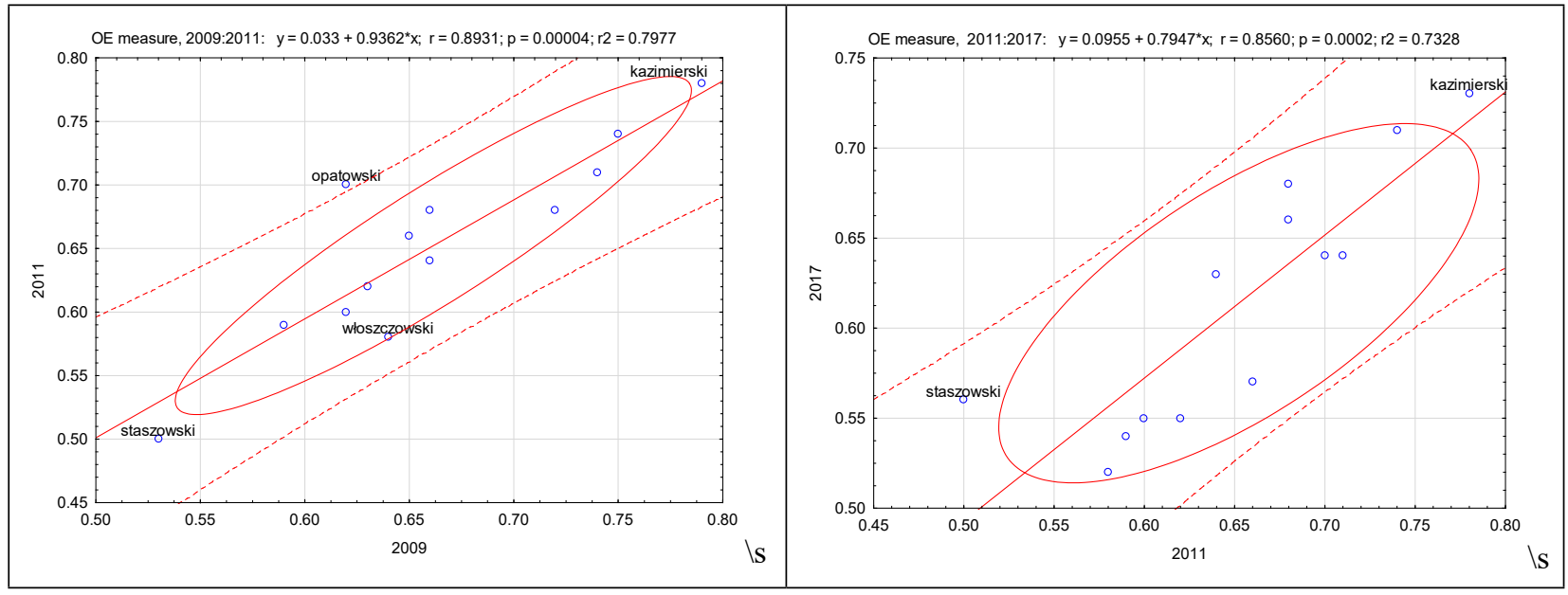

Source: own calculations of the authors based on the data from the Local Data Bank of Statistics Poland and Central Statistical Office

Regression analysis allows you to create a linear model. When creating it, decide which variables will be the explained variable and which variables will be the explanatory one. The regression model describing the dependence of variables takes the form:

$\mathrm{f}\left(\mathrm{OE}_{\text {competitiveness }}\right)=\sum$ (employed in agriculture, employed in industry, entities entered in the register per 1000 population, persons conducting professional, scientific and technical activities per 1000 inhabitants, unemployment rate, total migration balance for permanent residence per 1000 inhabitants, sold production of industry per capita, investment outlays in enterprises per capita, gross value of fixed assets in enterprises per capita, poviat own income of poviats, poviat investment expenditure per capita, total forest land area).

The results of the regression analysis for the synthetic measure show that the presented regression model allows explaining $\mathrm{R}=0.949$ variable variations. The high values of the $\mathrm{F}$ statistics $(52.31)$ and the corresponding level of probability $\mathrm{p}$ confirm the statistical significance of the linear model. The t-Student statistic value for the $\mathrm{p}$ parameter means that all parameters are statistically significant. The value of the determination coefficient $(\mathrm{R} 2=$ 0.931 ) indicates a good fit of the regression model to the data (Table 5).

Table 5.

KMNK estimation with dependent variable synthetic measure (OE)

\begin{tabular}{|l|c|c|c|c|c|}
\hline & Rate & Standard error & t-Student's & p-value & \\
\hline constant & 1.34107 & 0.136661 & 9.813 & $<0.0001$ & $* * *$ \\
\hline working in agriculture & -0.523235 & 0.121484 & -4.307 & 0.0002 & $* * *$ \\
\hline working in industry & -0.398506 & 0.133569 & -2.984 & 0.0059 & $* * *$ \\
\hline
\end{tabular}




\begin{tabular}{|c|c|c|c|c|c|c|}
\hline $\begin{array}{l}\text { persons conducting professional, scientific } \\
\text { and technical activities per } 1000 \text { inhabitants }\end{array}$ & -0.00460970 & 0.000896491 & -5.142 & \multicolumn{2}{|c|}{$<0.0001$} & $* * *$ \\
\hline unemployment rate & 0.00398883 & 0.000998886 & 3.993 & \multicolumn{2}{|c|}{0.0004} & $* * *$ \\
\hline sold production of industry & $-8.69723 e-06$ & $4.47916 \mathrm{e}-06$ & -1.942 & \multicolumn{2}{|c|}{0.0623} & $*$ \\
\hline investment outlays in enterprises & $-4.22669 \mathrm{e}-06$ & $2.12659 \mathrm{e}-06$ & -1.988 & \multicolumn{2}{|c|}{0.0567} & $*$ \\
\hline gross value of fixed assets & $-1.39998 \mathrm{e}-06$ & $3.38312 \mathrm{e}-07$ & -4.138 & \multicolumn{2}{|c|}{0.0003} & $* * *$ \\
\hline poviat own revenues & $-8.51890 \mathrm{e}-05$ & $4.66759 \mathrm{e}-05$ & -1.825 & \multicolumn{2}{|c|}{0.0787} & $*$ \\
\hline investment expenditure of poviats & -0.000166035 & $4.80431 \mathrm{e}-05$ & -3.456 & \multicolumn{2}{|c|}{0.0018} & $* * *$ \\
\hline forest land area & $-6.51252 \mathrm{e}-06$ & $6.81284 \mathrm{e}-07$ & -9.559 & \multicolumn{2}{|c|}{$<0.0001$} & $* * *$ \\
\hline Arithmetic mean of the dependent variable & 0.642564 & \multicolumn{3}{|c|}{ Standard deviation of the dependent variable } & \multicolumn{2}{|c|}{0.073188} \\
\hline Sum of residual squares & 0.010340 & \multicolumn{3}{|c|}{ Residual Standard Error } & \multicolumn{2}{|c|}{0.019217} \\
\hline $\begin{array}{l}\text { Determining coefficient } \\
\mathrm{R}-\text { square }\end{array}$ & 0.949200 & \multicolumn{3}{|c|}{ Corrected R-square } & \multicolumn{2}{|c|}{0.931057} \\
\hline $\mathrm{F}(10,28)$ & 52.31795 & \multicolumn{3}{|c|}{ P-value for the F test } & \multicolumn{2}{|c|}{$1.92 \mathrm{e}-15$} \\
\hline Logarithm of credibility & 105.2496 & \multicolumn{3}{|c|}{ Akaike information criterion } & \multicolumn{2}{|c|}{-188.4992} \\
\hline Bayesian information criterion & -170.2000 & \multicolumn{3}{|c|}{ Hannan-Quinn information criterion } & \multicolumn{2}{|c|}{-181.9336} \\
\hline
\end{tabular}

observations used 1-39

Source: own calculations of the authors based on the data from the Local Data Bank of Statistics Poland and Central Statistical Office

\section{Summary}

The competitiveness of the local economy is highly dependent on the processes taking place in the so-called development centers and the availability of endogenous resources. The center can get rich at the expense of peripheral areas (e.g. by attracting human capital).

The activities of poviats are of a multi-criteria category, their level of effectiveness is affected by location rents, finances, economic and infrastructural potential, natural resources, etc. A characteristic feature of them is the effect of leaching, e.g. human capital, social or economic potential.

The presented methods allow the identification of areas with a higher / lower level of performance effectiveness, and then programming their support from public funds under regional policy. It can be a helpful tool for local authorities assessing the accuracy of past decisions and the effectiveness of regional management instruments used in the past.

The value of the synthetic measure allowed dividing the communes of the Świętokrzyskie Province into 4 groups. Small groups in time and space can be observed between the groups. Włoszczowski, Kielcki and Buski poviats were high in the ranking. At the other end of the ranking were Pińczowski, Skarżyski, Kazimierski. The synthetic measure in 2017 ranged from 0.52 (Włoszczowski poviat, the best unit) to 0.73 (Kazimierski, the weakest unit), in 20090.53 (Staszowski) to 0.79 (Kazimierski) respectively.

\section{Bibliography}

1. Adamczyk A., Dawidowicz D., 2016, Wartość informacyjna wskaźników oceny kondycji finansowej jednostek samorządu terytorialnego, Ekonomiczne Problemy Usług nr 125, p. 25-36.

2. Chądzyński J., Nowakowska A., Przygodzki Z., 2007, Region i jego rozwój w warunkach globalizacji, Wyd. CeDeWu, Warszawa, p. 106.

3. Dziekański P., 2016, Spatial Differentiation of the Financial Condition of the Świętokrzyskie Voivodship Counties, Barometr Regionalny, Tom $14 \mathrm{nr} 3$.

4. Dziekański P., 2018, Ocena efektywności funkcjonowania gmin województwa świętokrzyskiego w świetle ekonomii instytucjonalnej (analiza wielowymiarowa), Uniwersytet Jana Kochanowskiego w Kielcach, Kielce.

5. Dziekański P., Spatial changes and assessment of the financial condition of local government units in the context of the income structure [In:] Formankova S., International Conference on Management (ICoM), Trends of Management in the Contemporary Society (Peer-Reviewed Conference Proceedings), Brno 2016, Publisher: Mendelova univerzita v Brně.

6. Dziekański P., Wyszkowski A., 2018, Ocena przestrzennego zróżnicowania sytuacji finansowej gmin województwa świętokrzyskiego z wykorzystaniem miary syntetycznej, Optimum. Economic Studies, nr 1 (91), p. 219-238.

7. Jóźwiak M.A., Jóźwiak M., Strzyż M., 2010, Predyspozycje naturalne regionu świętokrzyskiego do rozwoju turystyki, Krajobraz a Turystyka, Prace Komisji Krajobrazu Kulturowego Nr 14, Komisja Krajobrazu Kulturowego PTG, Sosnowiec.

8. Kisiała W., Stępiński B. (ed.), 2013, Rola obszarów metropolitalnych w polityce regionalnej i rozwoju regionalnym, Wydawnictwo UE w Poznaniu, Poznań.

9. Klasik A., 2002, Strategie regionalne. Formułowanie i wprowadzanie w życie, AE, Katowice, p. 22-23. 
10. Kosiedowski W., 2008, Zarządzanie rozwojem regionalnym i lokalnym [In:] Gospodarka regionalna i lokalna, red. Z. Strzelecki, PWN, Warszawa, p. 232 i n.

11. Kuciński K., 1997, Konkurencyjność jako zagadnienie regionalne, IFGN, SGH, Warszawa, p. 1.

12. Kudłacz T., 2001, Rozwój regionalny Polski lat 90. - ocena dominujących procesów oraz spodziewanych tendencji [In:] Polityka regionalna państwa pośród uwikłań instytucjonalno-regulacyjnych, red. Szomburg J., IBnGR, Gdańsk, p.30.

13. Kukuła K., 2000, Metoda unitaryzacji zerowanej, PWN, Warszawa; A. Młodak, 2006, Analiza taksonomiczna w statystyce regionalnej, Difin, Warszawa.

14. Malina A., 2004, Wielowymiarowa analiza przestrzennego zróżnicowania struktury gospo-darki Polski według województw, Wyd. Akademii Ekonomicznej w Krakowie, Kraków, p. 96-97.

15. Markowski T., 2005, Przedmiotowa i podmiotowa konkurencyjność regionów [In:] T. Czyż, H. Rogacki (ed.), Współczesne problemy i koncepcje teoretyczne badań przestrzenno-ekonomicznych, z. 219, PAN KPZK, Warszawa, p. 28-30.

16. Markowski T., 2001, Stymulowanie i regulowanie konkurencyjności w świetle procesów globalizacji gospodarki, Samorząd Terytorialny, nr 3, p. 30.

17. Markowski T., Stawasz D. (ed.), 2001, Ekonomiczne i środowiskowe aspekty zarządzania rozwojem miast i regionów, Łódź, p. 91.

18. Mioduchowska-Jaroszewicz E., 2013, Metody i kierunki oceny kondycji finansowej jednostek samorządów terytorialnych, ZN US, nr 786, Finansowe, Ubezpieczenia, nr 64/2, p. 127-140.

19. Oplotnik Z., Brezovnik B., 2004, Financing local government in Slovenia, Post-Communist Economies, Volume 16 , Issue 4.

20. Parysek J.J., 2001, Podstawy gospodarki lokalnej, Wyd. Nauk. Uniwersytetu Adama Mickiewicza, Poznań.

21. Patrzałek L., 2010, Finanse samorządu terytorialnego a koncepcje rozwoju lokalnego i regionalnego, Prace Naukowe Uniwersytetu Ekonomicznego we Wrocławiu 112, Finanse publiczne, p. 549-556

22. Podgórski K., 1991, Ustawowa regulacja zadań gminy jako jednostki samorządu terytorialnego, ST, nr 11-12, p. 21.

23. Rynio D., 2013, Kształtowanie nowej polityki regionalnej Polski w warunkach globalizacji i integracji, Monografie i Opracowania Uniwersytetu Ekonomicznego we Wrocławiu, nr 240, p. 357

24. Trojak M., Tokarski T. (ed.), 2013, Statystyczna analiza przestrzennego zróżnicowania rozwoju ekonomicznego i społecznego Polski, Wyd. UJ, Kraków.

25. Ustawa z dnia 8 marca 1990 r. o samorządzie gminnym (Dz. U. z 2001 r. Nr 142, poz. 1591 z późn. zm.).

26. Wysocki F., 1996, Metody statystycznej analizy wielowymiarowej w rozpoznawaniu typów struktury przestrzennej rolnictwa, Roczniki AR w Poznaniu, seria: Rozprawy Naukowe, z. 266, Poznań.

27. Wysocki F., 2010, Metody taksonomiczne w rozpoznawaniu typów ekonomicznych rolnictwa i obszarów wiejskich, Wydawnictwo Uniwersytetu Przyrodniczego w Poznaniu, Poznań.

28. Wysocki F., Lira J., 2005, Statystyka opisowa, Wydawnictwo Uniwersytetu Przyrodniczego w Poznaniu, Poznań.

29. Zakrzewska-Półtorak A., 2011, Zasoby endogeniczne jako czynnik rozwoju lokalnego i regionalnego. Studium przypadków wybranych gmin województwa dolnośląskiego, Prace Naukowe Uniwersytetu Ekonomicznego we Wrocławiu, nr 152, p. 579-588.

30. Zaucha J., 2012, Synteza aktualnego stanu wiedzy dotyczącej rozwoju sustensywnego i spójności terytorialnej w planowaniu przestrzennym (analiza dokumentów UE, BSR i PL), [In:] Planowanie przestrzenne w rozwoju zrównoważonym, Inspiracje Projektu EcoRegion, część I, UG, Gdańsk. 